\title{
Phosphorylation by Alkaline Phosphatase: Immobilization and Synthetic Potential
}

\author{
Lara Babich $^{1}$, Joana L. V. M. Peralta ${ }^{1}$, Aloysius F. Hartog ${ }^{1} \&$ Ron Wever $^{1}$ \\ ${ }^{1}$ Van't Hoff Institute for Molecular Sciences, University of Amsterdam, Amsterdam, the Netherlands \\ Correspondence: Ron Wever, Van't Hoff Institute for Molecular Sciences, University of Amsterdam, Science \\ Park 904, Amsterdam 1090 GD, the Netherlands. Tel: 31-20-525-5110. E-mail: r.wever@uva.nl
}

Received: May 23, 2013 Accepted: July 3, 2013 Online Published: July 24, 2013

doi:10.5539/ijc.v5n3p87 URL: http://dx.doi.org/10.5539/ijc.v5n3p87

\begin{abstract}
Phosphatases (AP, E.C. 3.1.3.1) are hydrolytic enzymes that naturally hydrolyse phosphomonoesters but in a so-called transphosphorylation reaction these enzymes are also able to transfer a phosphate group from phosphorylated compounds to alcoholic functions. This transphosphorylation catalysed by acid phosphatases using pyrophosphate as a phosphate donor has been studied in some detail. However, the acidic $\mathrm{pH}$ optimum of these enzymes limits some of their applications. The catalytic features of alkaline phosphatase are similar to the acid phosphatases and its alkaline $\mathrm{pH}$ optimum suggests a possible application of this enzyme in phosphorylation reactions which need to be carried out at higher $\mathrm{pH}$. Here we explore the synthetic potential of bovine intestine alkaline phosphatase (AP) in the phosphorylation of dihydroxyacetone (DHA) and glycerol using pyrophosphate $\left(\mathrm{PP}_{\mathrm{i}}\right)$ as phosphate donor. The phosphorylated compounds are intermediates in two multi-enzymatic cascade reactions for the synthesis of carbohydrates. The yields of dihydroxyacetone phosphate (DHAP) and glycerol-1-phosphate at $\mathrm{pH} 8(2.6 \mathrm{mM}$ and $2.2 \mathrm{mM}$, respectively) were comparable to the results obtained with the acid phosphatases at $\mathrm{pH} 4$. Nevertheless, when the cascade reactions were carried out at $\mathrm{pH} 8$, very low conversions were measured due to inactivation of the alkaline phosphatase by the product phosphate. To circumvent this inhibition, the alkaline phosphatase was immobilized on aldehyde-activated beads (Sepabeads EC-HA). The immobilization greatly diminished the inhibition by phosphate, and the immobilized alkaline phosphatase at $\mathrm{pH} 8$ gave the same conversions in the cascade reaction starting from DHA as obtained with the acid phosphatase at $\mathrm{pH}$. However, the immobilized enzyme was active for only one catalytic cycle and the beads could not be reused.
\end{abstract}

Keywords: alkaline phosphatase, phosphorylation, immobilization, dihydroxyacetone phosphate, glycerol-1-phosphate, cascade reaction, pyrophosphate

\section{Introduction}

The importance of phosphate esters as prodrugs, taste enhancers, nutritional supplements, and cosmetic ingredients has drawn the attention of chemists and prompted the development of efficient phosphorylation methods (Auriol et al., 2008; Heimbach et al., 2003; Scudder, Dwek, Rademacher, \& Jacob, 1991; Westheimer, 1987). In particular the mild reaction conditions and reduced production of waste encouraged the development of enzyme-based technologies. Moreover, in contrast to chemical procedures, enzymes carry out phosphorylations with high regio and stereoselectivity without the need of group protection (Crans \& Whitesides, 1985a; Crans \& Whitesides, 1985b; Gross, Abril, Lewis, Geresh, \& Whitesides, 1983; Li, Enomoto, Hayashi, Zhao, \& Aoki, 2010). Kinases are well-known phosphorylating enzymes which transfers a phosphate unit from ATP to a variety of acceptors but the large-scale application is impeded by the need of regenerating ATP and in addition these enzymes are specific for the substrate to be phosphorylated (Faber, 2004). However, some hydrolytic enzymes can circumvent these issues: the non-specific alkaline and acid phosphatases (Sträter, Lipscomb, Klabunde, \& Krebs, 1996).

These phosphatases catalyse in vivo the hydrolysis of phosphomonoesters to inorganic phosphate $\left(\mathrm{P}_{\mathrm{i}}\right)$ and the corresponding free alcohol. However, phosphatases are also able to carry out transphosphorylation reactions in which a phosphate unit is transferred from a donor (phosphomonoesters or pyrophosphate $\mathrm{PP}_{\mathrm{i}}$ ) to an acceptor alcohol. The transphosphorylation reaction is thought to be a reversible two-step reaction in which the affinity for $\mathrm{PP}_{\mathrm{i}}$, alcohol, or water determines whether hydrolysis, transphosphorylation, or dephosphorylation occur (Asano, 
Mihara, \& Yamada, 1999b; Pradines, Klaebe, Perie, Paul, \& Monsan, 1988, 1991; Reid \& Wilson, 1971; Tanaka, Hasan, Hartog, van Herk, \& Wever, 2003). The transphosphorylation reaction is essentially reversible and the equilibrium position depends on the conditions and the amount of reagents and products present in the reaction mixture. Thus, phosphatases are able to hydrolyze $\mathrm{PP}_{\mathrm{i}}$, transfer a phosphate to an acceptor alcohol, or hydrolyze phosphate esters.

The well-known acid phosphatases from Shigella flexneri (PhoN-Sf), Shigella enterica ser. typhimurium (PhoN-Se), and Morganella morganii have been widely used in the regioselectively phosphorylation of nucleosides such as inosine and guanosine to the corresponding 5'-phosphate derivatives (5'-IMP and 5'-GMP) used as taste enhancers (umami) (Asano, Mihara, \& Yamada, 1999a; Asano et al., 1999b; Low \& Saltiel, 1988; Mihara, Utagawa, Yamada, \& Asano, 2000; Mihara, Utagawa, Yamada, \& Asano, 2001; Tanaka et al., 2003), of glucose to glucose-6-phosphate, and of many other primary alcohols, such as glycerol and DHA (Babich et al., 2011; Tanaka et al., 2003; van Herk, Hartog, van der Burg et al., 2005; van Herk, Hartog, Schoemaker et al., 2006; van Herk, Hartog, Babich et al., 2009).

In contrast to acid phosphatase, which operates at $\mathrm{pH}$ values below 7 , alkaline phosphatases are only active between $\mathrm{pH} 7$ and 10. This enzyme contains four metal sites occupied by $\mathrm{Zn}^{2+}$ and $\mathrm{Mg}^{2+}$ ( $\mathrm{Le} \mathrm{Du}$, Stigbrand, Taussig, Menez, \& Stura, 2001; Millan, 2006; Stec, Holtz, \& Kantrowitz, 2000) and is a dimer of two identical subunits with a molecular weight of approximately $160 \mathrm{kDa}$ (Fernley, 1971). This enzyme shows hydrolytic activity towards many phosphomonoesters (Portmann, 1957; Stadtman, 1961) such as polyprenol phosphates (Koyama et al., 1990), sphingoid base 1-phosphate (Min, Yoo, E. Lee, Y. Lee, \& W. Lee, 2002), nucleotides (Billich, Stockhove, \& Witze, 1983), nucleotides (Billich, Stockhove, \& Witze, 1983), and aromatic phosphate esters (Breslow \& Katz, 1968; Edwards et al., 1990). The potential of alkaline phosphatase for synthetic enzymatic phosphorylation has been explored a long time ago by Pradines and co-workers (Pradines, Klaebe, Perie, Paul, \& Monsan, 1988, 1991). In 1988, they reported the phosphorylation of primary alcohols and other substrates using different phosphate donors (Pradines et al., 1988). Diols and polyols were selectively monophosphorylated with good yields, whereas simple aliphatic primary alcohols were not accepted as well as amino- and sulfur-containing alcohols. Good yields were obtained only at very high alcohol concentrations ( $>7 \mathrm{M})$. Only regioselectivity but no stereoselectivity was observed. Interestingly, the $\mathrm{pH}$ optima in the transphosphorylation reaction and in the hydrolysis differ, being $\mathrm{pH} 8.5$ and 5.8, respectively. The great potential of AP in the large-scale production of glycerol-1-phosphate starting from very high glycerol concentrations (up to $11 \mathrm{M}$ ) and phosphate or pyrophosphate was also demonstrated (Pradines et al., 1991). The AP was immobilized on corn grits (EURA-MA 60-100 mesh, a cellulose-based carrier) and it was shown that the immobilized enzyme was more resistant against inhibition by glycerol-1-phosphate and $\mathrm{P}_{\mathrm{i}}$. In a batch reactor with embedded enzyme or in a continuous packed-bed reactor yields with respect to pyrophosphate were obtained of $41.3 \%$ and only $18 \%$ glycerol-1-phosphate, respectively.

Given the similar catalytic features of alkaline and acid phosphatase, we investigated the potential of alkaline phosphatase in the phosphorylation of DHA and glycerol as already studied for the acid phosphatases PhoN-Se and PhoN-Sf. These phosphorylated alcohols are key intermediates in two enzymatic cascade reactions leading to the synthesis of carbohydrates (Figure 1) (Babich et al., 2011; van Herk, Hartog, Schoemaker et al., 2006; van Herk, Hartog, Babich et al., 2009). 


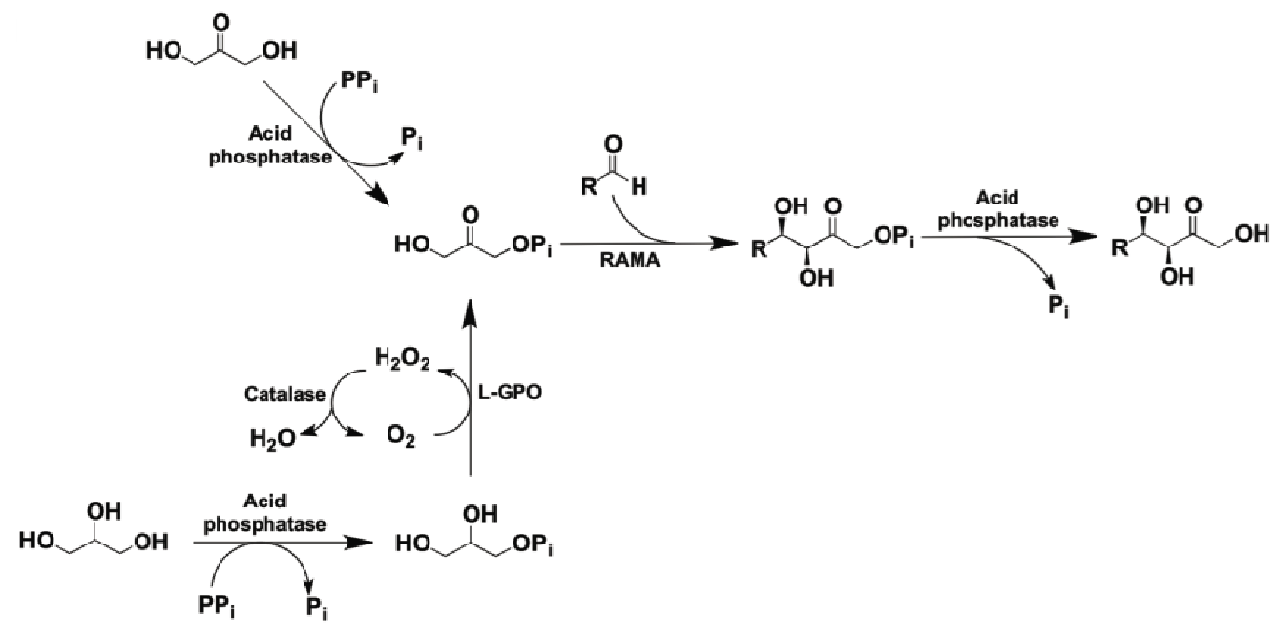

Figure 1. Scheme of the one-pot cascade reactions starting from DHA or glycerol at $\mathrm{pH} 6$

The acid phosphatase-mediated phosphorylation of glycerol with the phosphate donor $\mathrm{PPi}$ produces glycerol-1-phosphate. The L-enantiomer is then oxidized by glycerol phosphate oxidase in the presence of oxygen to produce DHAP. The oxidation takes place with concomitant formation of hydrogen peroxide, which is converted by catalase. In the next step of the cascade, DHAP reacts with the aldehyde catalyzed by rabbit muscle aldolase (RAMA) to provide the phosphorylated aldol product. This aldol product is ultimately dephosphorylated by PhoN-Sf leading to the enantio- and diasteromerically pure carbohydrate. This essentially irreversible step shifts the thermodynamic equilibrium of the cascade to aldol product once PPi becomes exhausted. It is also possible to start a cascade from DHA which is phosphorylated to DHAP and then converted into the final product.

In the two-enzyme three-steps cascade reaction the (acid) phosphatase using $\mathrm{PP}_{\mathrm{i}}$ phosphorylates DHA to DHAP, which is coupled by the fructose-1,6-bisphosphate aldolase (RAMA) to an aldehyde yielding a phosphorylated sugar. The third and last step is the dephosphorylation of the sugar by the phosphatase already present in the reaction (Figure 1) (van Herk et al., 2006). The other cascade reaction starts from glycerol and involves four enzymes and four steps (Babich et al., 2011). Glycerol is phosphorylated to glycerol-1-phosphate which is then oxidized by glycerol-1-phosphate oxidase (GPO) and molecular oxygen to DHAP and catalase removes the hydrogen peroxide formed. DHAP then undergoes the already described aldol condensation reaction by RAMA and the final dephoshorylation step yields the sugar. Both pathways gave very high yields of sugar, $60 \%$ in the two-enzyme cascade with DHA and $100 \mathrm{mM}$ propanal (van Herk et al., 2006) and complete conversion of $100 \mathrm{mM}$ propanal in the glycerol cascade reaction (Babich et al., 2011). Very high conversions were obtained with a genetically engineered mutant of PhoN-Se: the mutant V78L yielded $100 \%$ product in only 2 hours in the cascade reaction starting from DHA (van Herk et al., 2009).

These cascade reactions were carried out in one pot at $\mathrm{pH} 6$, which is neither the optimal condition for the acid phosphatase, nor for the aldolase, nor for the oxidase. PhoN-Sf and PhoN-Se are mostly active at $\mathrm{pH} 4-4.5$, whereas RAMA and GPO have a more alkaline pH optimum, between 7 and 8 . However, all the enzymes show activity at $\mathrm{pH}$ 6. At higher $\mathrm{pH}$ values, the activity of RAMA (and also GPO) is enhanced, but PhoN-Sf becomes inactive. Thus, alkaline phosphatase, which has a $\mathrm{pH}$ optimum around 8-9, may be a good substitute for the acid phosphatase since it would be possible to carry out reactions at higher $\mathrm{pH}$, maximizing the rate and activity of the aldolase and also of the oxidase, in case of the glycerol cascade reaction, resulting in higher yields or shorter reaction times. This work describes the phosphorylation of dihydroxyacetone and glycerol by alkaline phosphatase using $\mathrm{PP}_{\mathrm{i}}$, its immobilization on solid beads, and its use in cascade reactions.

\section{Method}

\subsection{Hydrolysis of PP ${ }_{i}$ by Alkaline Phosphatase and Inhibition Studies}

Alkaline phosphatase (AP) from bovine intestine was supplied by Sigma Aldrich and stored at $4{ }^{\circ} \mathrm{C}$ in $5 \mathrm{mM}$ Tris buffer $\mathrm{pH} 7$, containing $5 \mathrm{mM} \mathrm{MgCl}_{2}$ and $0.1 \mathrm{mM} \mathrm{ZnCl}_{2}$. AP activity was determined by a spectrophotometric assay using $p$-nitrophenol phosphate ( $p$ NPP) as substrate. The hydrolysis produces $p$-nitrophenol $(p \mathrm{NP})$, which absorbs at $405 \mathrm{~nm}$. The assay mixture contained $100 \mathrm{mM}$ of $p$ NPP in $1 \mathrm{M}$ diethanolamine (DEA, pH 9.8), 0.5 $\mathrm{mM} \mathrm{MgCl}$, and $0.1 \mathrm{mM} \mathrm{ZnCl}_{2} .10 \mu \mathrm{L}$ of a proper enzyme dilution was added to $1 \mathrm{~mL}$ of the assay mixture and 
allowed to react for 5 minutes at $20^{\circ} \mathrm{C}$. The absorbance was then monitored at $405 \mathrm{~nm}$ with a UV-Vis Cary-50 spectrophotometer. The activity was calculated using an extinction coefficient of $18.5 \mathrm{mM}^{-1} \mathrm{~cm}^{-1}$. One unit will hydrolyze $1 \mu \mathrm{mol}$ of $p \mathrm{NPP}$ per minute at $\mathrm{pH} 9.8$ at $20^{\circ} \mathrm{C}$. The activity test was carried out also in present of different concentrations of inorganic phosphate to verify whether the enzyme suffered from phosphate inhibition. Reactions were carried out in $1 \mathrm{M}$ DEA pH 8, $100 \mathrm{mM} p \mathrm{NPP}, 0.1 \mathrm{mM} \mathrm{ZnCl} 2,0.5 \mathrm{mM} \mathrm{MgCl} 2,6 \mathrm{U} / \mathrm{mL}$ AP and 10 , 25 , and $100 \mathrm{mM}$ of sodium phosphate at $20{ }^{\circ} \mathrm{C}$. After 5 minutes the absorbance was recorded at $405 \mathrm{~nm}$ and activity calculated as described above.

The time course of $\mathrm{PP}_{\mathrm{i}}$ hydrolysis was determined at $\mathrm{pH} 7$ and 8 with different concentrations of $\mathrm{PP}_{\mathrm{i}}(50,100$, and $250 \mathrm{mM}$ ) using $6 \mathrm{U} / \mathrm{mL}$ of AP, $0.1 \mathrm{mM} \mathrm{ZnCl}_{2}$, at $30^{\circ} \mathrm{C}$. The time course of the disappearance of $\mathrm{PP}_{\mathrm{i}}$ and formation of $P_{i}$ was determined every 30 minutes by HPLC analysis after 10-fold dilution of samples in water and after calibration with analytical grade standard solution of $\mathrm{PP}_{\mathrm{i}}$ and $\mathrm{P}_{\mathrm{i}}$. HPLC analysis was performed using an Alltech OA1000 organic acid column $(0.65 \times 30 \mathrm{~cm})$ equipped with a Dionex 580LPG pump and Dionex UVD-340 UV detector and Shodex RI-101 detector. The column was eluted with $25 \mathrm{mM} \mathrm{H}_{2} \mathrm{SO}_{4}$ at $0.4 \mathrm{~mL} / \mathrm{min}$ at room temperature. Chromeleon software was used for the acquisition and evaluation of the data. By adding $\mathrm{MgCl}_{2}$ the effect of $\mathrm{Mg}^{2+}$ on the rate of hydrolysis of $p \mathrm{NPP}$ was tested and the best ratio $\mathrm{Mg}^{2+} / \mathrm{PP}_{\mathrm{i}}$ was determined. The reactions were carried out with $100 \mathrm{mM} \mathrm{PP}, 0.1 \mathrm{mM} \mathrm{ZnCl}, 6 \mathrm{U} / \mathrm{mL} \mathrm{AP}$ at $\mathrm{pH} 8$ for 1 day at $30{ }^{\circ} \mathrm{C}$ with different concentrations of $\mathrm{MgCl}_{2}: 100 \mathrm{mM}\left(\mathrm{Mg}^{2+} / \mathrm{PP}_{\mathrm{i}}=1: 1\right), 66 \mathrm{mM}\left(\mathrm{Mg}^{2+} / \mathrm{PP}_{\mathrm{i}}=2: 3\right)$, and $50 \mathrm{mM}$ $\left(\mathrm{Mg}^{2+} / \mathrm{PP}_{\mathrm{i}}=1: 2\right)$. Every hour, samples were taken, diluted 10 -fold in water and analyzed by HPLC.

\subsection{Phosphorylation by Alkaline Phosphatase}

The phosphorylation of DHA to DHAP by AP was tested using $\mathrm{PP}_{\mathrm{i}}$ as phosphate donor. The time course and the $\mathrm{pH}$ dependency of the phosphorylation reaction were determined. Typical reaction mixtures contained $100 \mathrm{mM}$ DHA, $50 \mathrm{mM} \mathrm{PP}, 0.1 \mathrm{mM} \mathrm{ZnCl} 2,2,4$, or $6 \mathrm{U} / \mathrm{mL}$ of AP in a $\mathrm{pH}$ range between 7 and 10 at $30{ }^{\circ} \mathrm{C}$. The $\mathrm{pH}$ was set by addition of $\mathrm{HCl}$ or $\mathrm{NaOH}$ to the $\mathrm{PP}_{\mathrm{i}} / \mathrm{DHA}$ mixture until the desired value was reached. DHAP was determined spectrophotometrically using a coupled assay with L-glycerol-1-phosphate dehydrogenase (G3PDH), which reduces DHAP to L-glycerol-1-phosphate with concomitant oxidation of NADH to NAD ${ }^{+}$. The assay mixture contained $100 \mathrm{mM}$ Tris/acetate $\mathrm{pH} 7.5,1 \mathrm{U} / \mathrm{mL}$ G3PDH, and $0.16 \mathrm{mM}$ NADH. Every 10 minutes samples of $20 \mu \mathrm{L}$ of the phosphorylation reaction mixture were added to $980 \mu \mathrm{L}$ of assay mixture and incubated for 3 minutes. The absorbance was recorded at $340 \mathrm{~nm}$ and the amount of DHAP was calculated using an extinction coefficient of $6.22 \mathrm{mM}^{-1} \mathrm{~cm}^{-1}$.

Glycerol was also phosphorylated by AP into glycerol-1-phosphate using $\mathrm{PP}_{\mathrm{i}}$ as phosphate donor. Reaction mixtures contains $100 \mathrm{mM}$ glycerol, $50 \mathrm{mM} \mathrm{PP}, 0.1 \mathrm{mM} \mathrm{ZnCl}_{2}$, and $6 \mathrm{U} / \mathrm{mL} \mathrm{AP}$, at $\mathrm{pH} 8,30^{\circ} \mathrm{C}$. The product glycerol-1-phosphate was detected in a coupled enzymatic assay with G3PDH. The dehydrogenase oxidizes only L-glycerol-1-phosphate using $\mathrm{NAD}^{+}$and hydrazine. The formation of $\mathrm{NADH}$ can be detected

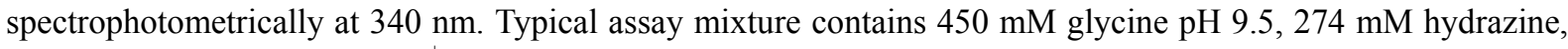
$2.4 \mathrm{mM}$ EDTA, $2.5 \mathrm{mM} \mathrm{NAD}^{+}$, and $20 \mathrm{U} / \mathrm{mL}$ G3PDH. Time points $(20 \mu \mathrm{L})$ were taken from the reaction of AP with glycerol and $\mathrm{PP}_{\mathrm{i}}$ and incubated for 5 minutes with $980 \mu \mathrm{L}$ of assay mixture at room temperature. Absorbance was recorded at $340 \mathrm{~nm}$ and the concentration of L-glycerol-1-phosphate calculated using an extinction coefficient of $6.22 \mathrm{mM}^{-1} \mathrm{~cm}^{-1}$. This value was then multiplied by a factor of 2 in order to take into account also the amount of D-glycerol-1-phosphate not detected by the assay.

\subsection{Immobilization of Alkaline Phosphatase}

Alkaline phosphatase was immobilized on three different epoxy-functionalized supports: Immobeads-150, purchased from Sigma-Aldrich, Sepabeads EC-EP and Sepabeads EC-HA, both purchased from Resindion. The latter beads posses a linker functionalized with an amino group, which has to be activated with glutardialdehyde. The activation was carried out in $100 \mathrm{mM}$ phosphate buffer, $\mathrm{pH} 8$ and $1.5 \%$ glutardialdehyde for 2 hours under rotation of the beads at room temperature. The beads were then washed three times with potassium phosphate buffer $20 \mathrm{mM}$, pH 7. The immobilization was performed on a $0.5 \mathrm{~mL}$ scale with $30 \mathrm{U} / \mathrm{mL}$ AP, $30 \mathrm{mM}$ potassium phosphate buffer $\mathrm{pH} 8,0.5 \mathrm{mM} \mathrm{MgCl}$, and $10 \mathrm{mg}$ (dry weight) of Immobeads, or $25 \mathrm{mg}$ (wet weight) of Sepabeads EC-EP or EC-HA glutardialdehyde activated beads. The Eppendorf tubes were then slowly rotated for $24 \mathrm{~h}$ at $20^{\circ} \mathrm{C}$. Afterwards, the beads were washed three times with $100 \mathrm{mM}$ potassium phosphate, $\mathrm{pH}$ 7. By testing the remaining activity in the supernatant using $p$ NPP the time course of the binding process was monitored.

\subsection{Cascade Reaction with Alkaline Phosphatase}

The two-enzyme cascade reaction was carried out with $500 \mathrm{mM} \mathrm{DHA}, 100 \mathrm{mM} \mathrm{PP}$, $100 \mathrm{mM}$ propanal, $0.1 \mathrm{mM}$ $\mathrm{ZnCl}_{2}, 6 \mathrm{U} / \mathrm{mL} \mathrm{AP}, 6 \mathrm{U} / \mathrm{mL}$ RAMA, at $\mathrm{pH} 7$ or 8 at $30^{\circ} \mathrm{C}$. At selected time samples were taken and diluted 
10-fold in water before the HPLC analysis with the same method described above. The cascade reaction was repeated under the same conditions with AP immobilized on Sepabeads EC-HA (50 $\mu \mathrm{L}$ of settled beads, $20 \mathrm{U})$ at $\mathrm{pH} 8$ in $1 \mathrm{~mL}$ scale. The time course of the product formation was measured and was compared to the reaction performed with immobilized acid phosphatase (PhoN-Sf, $25 \mu \mathrm{L}$ settled beads, $1 \mathrm{U}$ ) at pH 6 (Babich et al., 2012a) To investigate the reusability of the immobilized catalyst, fed-batch cascade reactions were carried out with both immobilized AP and PhoN-Sf under the conditions described above. The beads were incubated with the substrates and allowed to react for $24 \mathrm{~h}$. At the end of this first cycle, the supernatant containing the product and unreacted substrates was removed, the beads washed three times with $20 \mathrm{mM}$ potassium phosphate $\mathrm{pH} 8$ and incubated with fresh reaction mixture for another cycle.

A four-enzyme cascade reaction was performed with $\mathrm{AP}$ at $\mathrm{pH} 8$ in presence of $1 \mathrm{~mL}$ of $100 \mathrm{mM} \mathrm{PP}, 500 \mathrm{mM}$ glycerol, $100 \mathrm{mM}$ propanal, $0.1 \mathrm{mM} \mathrm{ZnCl}, \quad 10 \mathrm{U} / \mathrm{mL}$ catalase, $6 \mathrm{U} / \mathrm{mL}$ RAMA, $50 \mathrm{U} / \mathrm{mL}$ L-glycerol-3-phosphate oxidase (GPO), and $50 \mu \mathrm{L}$ of settled Sepabeads EC-HA with AP (approximately $20 \mathrm{U}$ ) at $30{ }^{\circ} \mathrm{C}$. The time course of the reaction was determined as described above for the DHA cascade reaction. A parallel reaction was performed with $1 \mathrm{U} / \mathrm{mL}$ PhoN-Sf at $\mathrm{pH} 6$ at the same conditions (Babich et al., 2011).

\section{Results}

\subsection{Hydrolysis of PP $P_{i}$ by Alkaline Phosphatase and Inhibition Studies}

Since AP is a hydrolytic enzyme, the rate of the hydrolysis of the phosphate donor $\mathrm{PP}_{\mathrm{i}}$ was determined at $\mathrm{pH} 7$ and 8. Table 1 shows the amount of $\mathrm{PP}_{\mathrm{i}}$ and $\mathrm{P}_{\mathrm{i}}$ present in the reactions after 4 hours incubation at $30{ }^{\circ} \mathrm{C}$ with different starting concentration of $\mathrm{PP}_{\mathrm{i}}$.

Table 1. Hydrolysis of $\mathrm{PP}_{\mathrm{i}}$ by alkaline phosphatase

\begin{tabular}{lllll}
\hline \multirow{2}{*}{$\mathrm{PP}_{\mathrm{i}}(\mathrm{mM})$} & \multicolumn{2}{l}{ Remaining $\mathrm{PP}_{\mathrm{i}}(\mathrm{mM})$} & \multicolumn{2}{l}{ Formed $\mathrm{P}_{\mathrm{i}}(\mathrm{mM})$} \\
\cline { 2 - 5 } & $\mathrm{pH} 7$ & $\mathrm{pH}$ & $\mathrm{pH} \mathrm{7}$ & $\mathrm{pH}$ \\
\hline 50 & 0.8 & 0.5 & 98 & 100 \\
100 & 67 & 35 & 66 & 130 \\
250 & 230 & 200 & 40 & 100 \\
\hline
\end{tabular}

Hydrolysis of various concentrations of $\mathrm{PP}_{\mathrm{i}}$ by $\mathrm{AP}(6 \mathrm{U} / \mathrm{mL})$ at $\mathrm{pH} 7$ and 8 and $30^{\circ} \mathrm{C}$ after 4 hours incubation. In the absence of the enzyme no hydrolysis of $\mathrm{PP}_{\mathrm{i}}$ occurs.

At both $\mathrm{pH} 7$ and $8,50 \mathrm{mM} \mathrm{PP}$ is completely hydrolysed by AP yielding $100 \mathrm{mM}$ of free phosphate. $100 \mathrm{mM}$ $\mathrm{PP}_{\mathrm{i}}$ is hydrolyzed faster at $\mathrm{pH} 8$ than at $\mathrm{pH} 7$ but the hydrolysis is not complete after 4 hours since complete hydrolysis should result in $200 \mathrm{mM}$ free phosphate. With $250 \mathrm{mM} \mathrm{PP}_{\mathrm{i}}$, the reaction is also faster at $\mathrm{pH} 8$ but the reaction is very slow and reaches a steady level with no further hydrolysis (data not reported). This suggests a possible inhibition by the substrate $\mathrm{PP}_{\mathrm{i}}$, as several authors already reported (Butterworth, 1968; Fernley \& Walker, 1967; Morton, 1955; Nayudu \& Miles, 1969). This is in contrast to the acid phosphatases PhoN-Sf and PhoN-Se, which completely consume $\mathrm{PP}_{\mathrm{i}}$ under similar conditions and which are not inhibited by $\mathrm{PP}_{\mathrm{i}}$ (Tanaka et al., 2003; van Herk et al., 2005). The inhibition could be due to the fact that AP is a zinc-dependent enzyme and $\mathrm{PP}_{\mathrm{i}}$ may chelate $\mathrm{Zn}^{2+}$ causing depletion of the metal from the active site and enzyme inactivation. Butterworth showed that for the pig kidney alkaline phosphatase the inhibitory concentration of $\mathrm{PP}_{\mathrm{i}}$ depended on the concentration of $\mathrm{Mg}^{2+}$ ions present in the mixture (Butterworth, 1968). Maximum pyrophosphatase activity was measured at a 1:1 $\mathrm{Mg}^{2+} / \mathrm{PP}_{\mathrm{i}}$ ratio, but inhibition was reported when the concentration of $\mathrm{Mg}^{2+}$ exceeded the total $\mathrm{PP}_{\mathrm{i}}$ concentration. Therefore, it was suggested that this alkaline phosphatase was most active towards the complex $\mathrm{MgPP}_{\mathrm{i}}{ }^{2-}$ and just slightly active toward the free $\mathrm{PP}_{\mathrm{i}}^{4}$. An excess of $\mathrm{Mg}^{2+}$ would also form the specie $\mathrm{Mg}_{2} \mathrm{PP}_{\mathrm{i}}$, which is a strong inhibitor. The presence of both species in solution would result in a competition and finally inhibition (Butterworth, 1968).

However, the effect of $\mathrm{Mg}^{2+}$ varies in AP from different sources. The duodenal alkaline phosphatase is most active when the ratio $\mathrm{Mg}^{2+} / \mathrm{PP}_{\mathrm{i}}$ is 2:3 (Nayudu \& Miles, 1969). In intestinal and liver AP other authors did not report the activity-enhancing effect of $\mathrm{Mg}^{2+}$ in 1: 1 ratio with $\mathrm{PP}_{\mathrm{i}}$ or its inhibitory effect at higher concentrations (Eaton \& Moss, 1967). To clarify this we measured the effect of different concentrations of $\mathrm{Mg}^{2+}$ ions on the $\mathrm{PP}_{\mathrm{i}}$ hydrolysis by the bovine intestine alkaline phosphatase under our reaction conditions. Figure 2 shows the rate of hydrolysis of $100 \mathrm{mM} \mathrm{PP}$ in absence and in presence of different concentrations of $\mathrm{MgCl}_{2}$. 


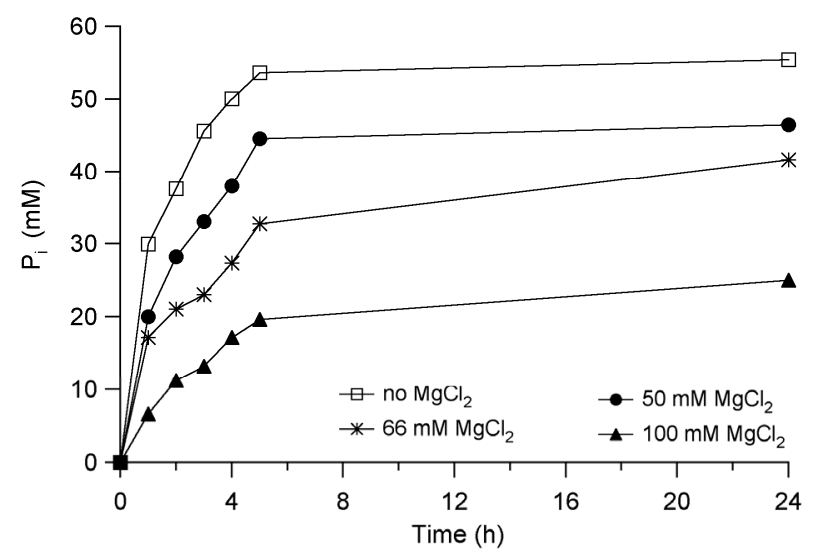

Figure 2. Rate of hydrolysis of $\mathrm{PP}_{\mathrm{i}}$ in presence of various concentrations of $\mathrm{MgCl}_{2}$. Reaction mixtures contain $100 \mathrm{mM} \mathrm{PP}_{\mathrm{i}}, 0,50,66$, or $100 \mathrm{mM} \mathrm{MgCl}_{2}$, at $\mathrm{pH} 8,30^{\circ} \mathrm{C}$. The $\mathrm{PP}_{\mathrm{i}} / \mathrm{Mg}^{2+}$ ratios are 2:1 for $50 \mathrm{mM} \mathrm{MgCl}_{2}, 3: 2$ for $66 \mathrm{mM} \mathrm{MgCl}_{2}$, and 1:1 for $100 \mathrm{mM} \mathrm{MgCl} 2$

Not only the initial rate of the reaction is decreased but also the extent of the hydrolysis is strongly affected by $\mathrm{MgCl}_{2}$. This demonstrates that the pyrophosphatase activity of the alkaline phosphatase from bovine intestine is not positively affected by $\mathrm{Mg}^{2+}$, but rather is inhibited. Thus the complex $\mathrm{MgPP}_{\mathrm{i}}{ }^{2-}$ is not the true substrate for intestinal AP. This experiment also shows that the hydrolysis of $\mathrm{PP}_{\mathrm{i}}$ is suppressed and after 24 hours incubation, no more phosphate is produced. This may be due to inhibition of AP by phosphate, the product of the reaction, but in presence of $\mathrm{MgCl}_{2}$ less phosphate is formed than in its absence. This indicates that the enzyme is not only inhibited by phosphate but also by $\mathrm{Mg}^{2+}$, whose inhibitory effect is additive to the inhibition by phosphate.

To investigate the inhibition of AP by the formed $\mathrm{P}_{\mathrm{i}}$ the hydrolysis of $\mathrm{PP}_{\mathrm{i}}$ was studied in presence of various concentrations of $\mathrm{PP}_{\mathrm{i}}$ and $\mathrm{P}_{\mathrm{i}}$ in order to determine the origin of the inhibition of the enzyme activity. When the hydrolysis of $100 \mathrm{mM} p$ NPP was studied at different concentrations of $\mathrm{P}_{\mathrm{i}}(10,25$, and $100 \mathrm{mM})$ partial inhibition $\left(15 \%\right.$ in respect to the reaction without $\mathrm{P}_{\mathrm{i}}$ ) occurred already with $10 \mathrm{mM} \mathrm{P}_{\mathrm{i}}$, while the activity was only $40 \%$ when $25 \mathrm{mM} \mathrm{P}_{\mathrm{i}}$ was present. The enzyme was completely inactive in $100 \mathrm{mM} \mathrm{P} \mathrm{P}_{\mathrm{i}}$. This suggests that $100 \mathrm{mM} \mathrm{PP}$ will never be hydrolyzed completely, because $\mathrm{P}_{\mathrm{i}}$ will inhibit the alkaline phosphatase already at low concentrations as has already been reported by many authors (Morton, 1955; Portmann, 1957).

\subsection{Phosphorylation by Alkaline Phosphatase}

Despite the inhibition of alkaline phosphatase by $\mathrm{P}_{\mathrm{i}}$ which is formed during hydrolysis of $\mathrm{PP}_{\mathrm{i}}$, the enzyme was tested in transphosphorylation reaction of DHA and glycerol at $\mathrm{pH} 9$ and the conversions were compared with the ones obtained with the acid phosphatases PhoN-Se and PhoN-Sf at pH 4. In order to optimize the DHAP formation two parameters were investigated: the AP concentration and the $\mathrm{pH}$ dependency. As Figure $3 \mathrm{~A}$ shows the concentration of DHAP formed increased when the concentration of enzyme was increased from 2 to $4 \mathrm{U} / \mathrm{mL}$, although $6 \mathrm{U} / \mathrm{mL}$ does not result in a further increase of product. The maximal concentration of DHAP formed was $2.2 \mathrm{mM}$ and no dephosphorylation was observed within the first 140 minutes. That no hydrolysis of DHAP occurs is probably caused by inactivation of the AP by the phosphate formed. The results obtained from these experiments agree with previous studies performed with acid phosphatases PhoN-Se and PhoN-Sf in which respectively 1.6 and $3 \mathrm{mM}$ of DHAP were obtained at $\mathrm{pH} 4$, using the same concentrations of $\mathrm{PP}_{\mathrm{i}}$ and DHA (van Herk, Hartog, Schoemaker et al., 2006; van Herk, Hartog, Babich et al., 2009). In contrast the acid phosphatases are not inhibited by phosphate formed and phosphorylation of DHA was rapidly followed by dephosphorylation of DHAP. 

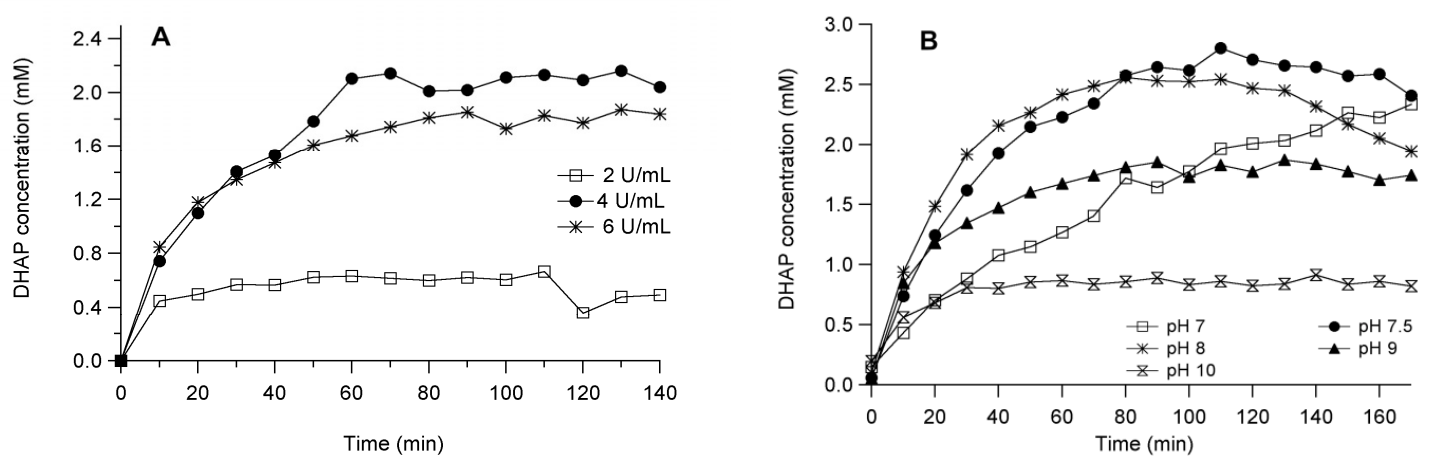

Figure 3. A) Time course of the phosphorylation of DHA by three different concentrations of AP $(2,4$, and 6 $\mathrm{U} / \mathrm{mL}$ ). Reaction mixtures contains $100 \mathrm{mM} \mathrm{DHA}, 50 \mathrm{mM} \mathrm{PP}_{\mathrm{i}}$, at $\mathrm{pH}$ 9, at $30^{\circ} \mathrm{C} . \mathrm{B}$ ) $\mathrm{pH}$ dependency of the phosphorylation of DHA. Reaction mixtures contains $100 \mathrm{mM} \mathrm{DHA}, 50 \mathrm{mM} \mathrm{PP}, 6 \mathrm{U} / \mathrm{mL} \mathrm{AP}$, at $30^{\circ} \mathrm{C}$, and $\mathrm{pH}$ values from 7 to 10

In Figure 3B the $\mathrm{pH}$ dependency of the phosphorylation reaction is depicted. The highest concentration of DHAP $(2.8 \mathrm{mM})$ was obtained at $\mathrm{pH} 7.5$ after 110 minutes incubation. Higher $\mathrm{pH}$ values resulted in a considerably lower concentration of DHAP. The combination of yield and reaction time ( $2.6 \mathrm{mM}$ after 80 minutes) suggested that a $\mathrm{pH}$ of 8 would be a good starting point for further optimization.

The phosphorylation of glycerol to glycerol-1-phosphate by AP using $\mathrm{PP}_{\mathrm{i}}$ as phosphate donor at the same conditions used for the phosphorylation of DHA was also studied. Pradines and coworkers already showed that AP was able to produce $82 \mathrm{mM}$ glycerol-1-phosphate (55\% yield based on $\mathrm{PP}_{\mathrm{i}}$ ) using a very high concentration of glycerol $(7.5 \mathrm{M})$ and $150 \mathrm{mM} \mathrm{PP}$, with a $95: 5$ ratio of glycerol-1-phosphate vs. glycerol-2-phosphate. The highest glycerol-1-phosphate concentration, $0.2 \mathrm{M}$, was obtained after 500 hours incubation at $40^{\circ} \mathrm{C}$ in a mixture of $11 \mathrm{M}$ glycerol, $0.4 \mathrm{M}$ phosphate, $500 \mathrm{U} / \mathrm{mL} \mathrm{AP}$, at $\mathrm{pH}$ 7.9. When we investigated the formation of glycerol-1-phosphate with $100 \mathrm{mM}$ glycerol, $50 \mathrm{mM} \mathrm{PP}, 6 \mathrm{U} / \mathrm{mL} \mathrm{AP}$, at $\mathrm{pH} 8$ and at $30{ }^{\circ} \mathrm{C}$ a maximal concentration of $2.2 \mathrm{mM}$ DL-glycerol-1-phosphate was found in 4 hours and also in this case no dephosphorylation was observed. The same amount of glycerol-1-phosphate was obtained with PhoN-Sf at pH 6 (data not reported). These results suggest that the alkaline phosphatase behaves similarly to the acid phosphatase in the phosphorylation of DHA and glycerol, yielding comparable amounts of products. Although the AP suffers from phosphate inhibition, these results indicate that AP is potentially useful in the cascade reactions starting from DHA and glycerol in particular at higher $\mathrm{pH}$ values.

\subsection{Immobilization of Alkaline Phosphatase}

To allow the reuse of the catalyst and to improve its catalytic stability alkaline phosphatase was immobilized. Furthermore immobilization may also prevent inactivation by phosphate. Immobilization of AP was reported on glass beads, agarose (Sepharose), the epoxy carrier Eupergit-C (Taylor, 1985), corn grits (Pradines et al., 1991), and a macroporous chitosane based carrier earlier (Zubriene, Budriene, Lubiene, \& Dienys, 2002). In this study AP was immobilized on methacrylic porous beads: Immobeads-150, Sepabeads EC-EP, and Sepabeads EC-HA. Immobeads-150 and Sepabeads EC-EP contain epoxy functions, which react with the amino groups of the lysine residues present on the surface of the enzyme. Sepabeads EC-HA contains a longer linker with an amino group which reacts with glutardialdehyde during the activation process. After the activation, the aldehyde on the linker will react with the lysine residues of the enzyme. When the enzyme was exposed to Immobeads-150 and Sepabeads EC-EP the activity in the supernatant did not decrease. This means that the enzyme was not immobilized on these beads. In contrast, with the Sepabeads EC-HA aldehyde activated beads the decrease in activity in the supernatant was very rapid. Complete immobilization was observed already after 4 hours. The difference in binding to the different types of beads can be explained by a low reactivity of the enzyme towards epoxy-functionalized beads and apparently a higher affinity for the longer spacer carrying aldehyde groups of the Sepabeads EC-HA. Length, flexibility, hydrophobicity/hydrophilicity, and charged/neutral character of spacers are known to have a strong influence on the outcome of the immobilization process, influencing not only the binding capability, but also retention of activity, stability, and catalytic performances. 


\subsection{Cascade Reaction Using Alkaline Phosphatase}

In order to investigate the synthetic potential of the alkaline phosphatase, cascade reactions as illustrated in Figure 1 starting from DHA were carried out with the soluble and immobilized AP. Typically two-enzyme cascade reactions contain $100 \mathrm{mM} \mathrm{PP}$, $500 \mathrm{mM}$ DHA, $100 \mathrm{mM}$ propanal, $6 \mathrm{U} / \mathrm{mL}$ AP, $6 \mathrm{U} / \mathrm{mL}$ RAMA, $\mathrm{pH} 8$ at $30^{\circ} \mathrm{C}$. Figure 4 shows the time course of the formation of the aldol adduct 5,6-dideoxy-D-threo-2-hexulose, the concentrations of phosphate liberated and phosphorylated product formed using AP.

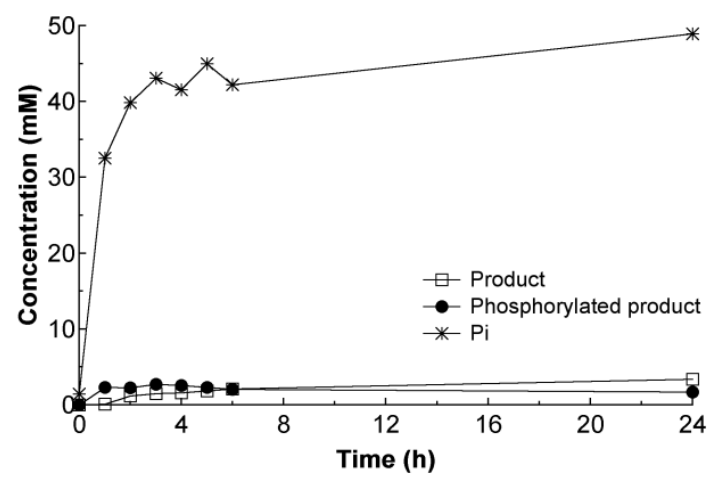

Figure 4. Time course of the two-enzyme cascade reaction using soluble AP. The reaction mixture contains 100 $\mathrm{mM} \mathrm{PP}$, $500 \mathrm{mM}$ DHA, $100 \mathrm{mM}$ propanal, $6 \mathrm{U} / \mathrm{mL}$ AP, $6 \mathrm{U} / \mathrm{mL}$ RAMA, $\mathrm{pH} 8$ at $30^{\circ} \mathrm{C}$

A large amount of $\mathrm{P}_{\mathrm{i}}$ is formed initially, however, very little product is synthesized, less than $3 \mathrm{mM}$. It is also clear that the reaction proceeds very fast in the first 3 hours of incubation, and then it slows down without completely hydrolyzing $\mathrm{PP}_{\mathrm{i}}$ after $24 \mathrm{~h}$. Also the carbohydrate is still phosphorylated even after $24 \mathrm{~h}$. This is certainly due to AP inhibition by $\mathrm{P}_{\mathrm{i}}$.

The cascade reaction was repeated using the same conditions with the immobilized enzyme on Sepabeads EC-HA, to verify whether the immobilized enzyme was still active and whether the immobilization suppressed the inactivation by phosphate. The same reaction was performed also with acid phosphatase previously immobilized on Immobeads-150 (Babich et al., 2012a; van Herk et al., 2006). To limit the amount of free phosphate produced and thus limiting the inactivation of AP only $100 \mathrm{mM} \mathrm{PP} \mathrm{i}_{\mathrm{i}}$ was added. For comparison in the experiment with PhoN-Sf the same concentration of $\mathrm{PP}_{\mathrm{i}}$ was used. In Figure 5 the time course of the formation of the product and phosphorylated product is shown. Although the AP is slower than the PhoN-Sf, after $24 \mathrm{~h}$ the same conversion is reached $(30-33 \mathrm{mM}$, as calculated from the initial concentration of propanal).

AP dephosphorylates the phosphorylated product with slower rate than PhoN-Sf, but the product is completely hydrolyzed at the end of the reaction after $24 \mathrm{~h}$. Phosphate formation after $24 \mathrm{~h}(180 \mathrm{mM})$ was equal with both phosphatases. These data suggest that immobilized AP is less susceptible by inactivation by phosphate and that immobilization greatly improved the efficiency of this enzyme, opening the way for new applications. 


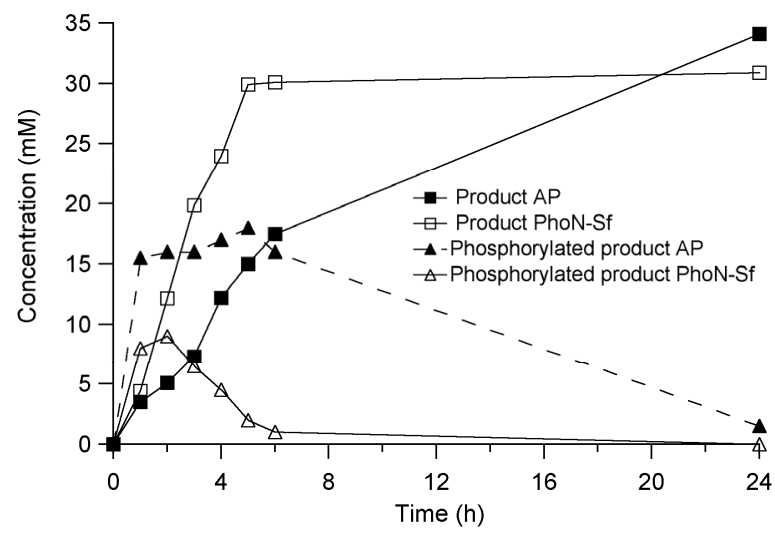

Figure 5. Time course of the formation of product and phosphorylated product in the two-enzyme cascade reaction using immobilized AP or immobilized PhoN-Sf. Reaction mixtures contain $500 \mathrm{mM} \mathrm{DHA}, 100 \mathrm{mM} \mathrm{PP}$, $100 \mathrm{mM}$ propanal, RAMA $6 \mathrm{U} / \mathrm{mL}, 20 \mathrm{U} / \mathrm{mL}$ immobilized AP at $\mathrm{pH} 8$ or $1 \mathrm{U} / \mathrm{mL}$ immobilized PhoN-Sf at $\mathrm{pH}$, at $30{ }^{\circ} \mathrm{C}$

Once the suitability of immobilized AP in the cascade reaction was established, the reusability of the catalyst was checked. The cascade reaction was performed with immobilized AP and immobilized PhoN-Sf and at the end of every cycle of $24 \mathrm{~h}$, the beads were washed and incubated with fresh reaction mixture consisting of $500 \mathrm{mM}$ DHA, $100 \mathrm{mM} \mathrm{PP}, 100 \mathrm{mM}$ propanal and RAMA for another cycle. During the first cycle, $34 \mathrm{mM}$ and $32 \mathrm{mM}$ of product were obtained using immobilized PhoN-Sf and immobilized AP, respectively. The beads were then washed and incubated with fresh reaction mixture. After 24h, at the end of the second cycle, PhoN-Sf beads formed $25 \mathrm{mM}$ of product whereas the AP beads lost most of their activity and gave only $6 \mathrm{mM}$ of product. Also nearly no $\mathrm{PP}_{\mathrm{i}}$ hydrolysis occurred. Therefore, it is clear that on one hand immobilization protects AP from inactivation by $\mathrm{P}_{\mathrm{i}}$ yielding a reasonable amount of product in the cascade reaction, but on the other hand immobilization does not stabilize AP sufficiently during turnover and the catalyst cannot be used for more than one cycle.

The alkaline phosphatase was also employed in the cascade reaction starting from glycerol (Figure 1) (Babich et al., 2011). In this cascade glycerol $(500 \mathrm{mM})$ is phosphorylated by $\mathrm{PP}_{\mathrm{i}}$ and the product DL-glycerol-1-phosphate is oxidized by L-glycerol-1-phosphate oxidase (GPO) using oxygen and generating hydrogen peroxide, which is eliminated by catalase. DHAP undergoes then aldol coupling with propanal as in the cascade reaction starting from DHA. The glycerol cascade was carried out in presence of immobilized AP at pH $8(20 \mathrm{U} / \mathrm{mL})$ and for comparison with immobilized PhoN-Sf at pH $6(1 \mathrm{U} / \mathrm{mL})$ with $0.5 \mathrm{M}$ glycerol, $100 \mathrm{mM} \mathrm{PP}$, $100 \mathrm{mM}$ propanal, $10 \mathrm{U} / \mathrm{ml}$ catalase, $6 \mathrm{U} / \mathrm{ml}$ RAMA and $50 \mathrm{U} / \mathrm{ml} \mathrm{GPO}$, at $30^{\circ} \mathrm{C}$. After $24 \mathrm{~h}$ incubation, the reaction with AP yielded only $3 \mathrm{mM}$ of product versus $50 \mathrm{mM}$ of product given by PhoN-Sf. However, $\mathrm{PP}_{\mathrm{i}}$ was completely hydrolyzed and thus the immobilized AP was not inhibited by phosphate, as seen before. The low yield may be explained by a slower rate of glycerol-1-phosphate formation that limits the overall performance of the cascade reaction. One way to study this is to have more AP present in the incubation or to increase the concentration of glycerol to $3 \mathrm{M}$. The cascade reaction was therefore carried out with $3 \mathrm{M}$ glycerol and indeed a higher yield (30 $\mathrm{mM}$ ) of product was obtained. The same reaction carried out with PhoN-Sf yielded complete conversion. This may relate to $K_{m}$ value of AP for glycerol, which may be even higher than the $K_{m}$ of PhoN-Sf for glycerol (0.7 M) (Babich et al., 2011).

\section{Discussion}

In this work the potential use of alkaline phosphatase in phosphorylation reactions has been investigated. This enzyme shares an overall reaction mechanism with the well-studied acid phosphatases PhoN-Sf and PhoN-Se, but it has a pH optimum at more alkaline values. This suggests the enzyme could substitute the acid phosphatase when more alkaline conditions are required. Most aldolases have a $\mathrm{pH}$ optimum in the range $\mathrm{pH} 7$ to 8 and cascade reactions using phosphatase and aldolase could be more efficient when performed at higher $\mathrm{pH}$. Furthermore the AP is commercially available in contrast to the bacterial acid phosphatases. As shown by us $\mathrm{PP}_{\mathrm{i}}$ did not inhibit the alkaline phosphatase from bovine intestine, but the product of the reaction, $\mathrm{P}_{\mathrm{i}}$, had a strong inhibitory effect on the activity of AP as found by many authors (Butterworth, 1968; Fernley \& Walker, 1967; 
Morton, 1955; Nayudu \& Miles, 1969). Already at $10 \mathrm{mM}$ of $\mathrm{P}_{\mathrm{i}}$ the hydrolysis of $\mathrm{PP}_{\mathrm{i}}$ was inhibited for $10 \%$ and at $25 \mathrm{mM} \mathrm{P} \mathrm{P}_{\mathrm{i}} 40 \%$ inhibition was found. Nevertheless, the phosphorylation of $100 \mathrm{mM}$ DHA by AP at $\mathrm{pH} 8.0$ yielded about $2.5 \mathrm{mM}$ of DHAP which is about the same as that found for PhoN-Se and PhoN-Sf at pH 4 (1.6 and $3 \mathrm{mM}$ of DHAP, respectively) at the same concentrations of $\mathrm{PP}_{\mathrm{i}}$ and DHA (van Herk, Hartog, Schoemaker et al., 2006; van Herk, Hartog, Babich et al., 2009). Similarly, $100 \mathrm{mM}$ glycerol was phosphorylated by AP and $\mathrm{PP}_{\mathrm{i}}$ to same extent at $\mathrm{pH} 8$ as found for PhoN-Se and PhoN-Sf at pH 6. However, AP in contrast to PhoN-Se and PhoN-Sf, did not dephosphorylate DHAP or glycerol-1-phosphate because of the inhibition by the $\mathrm{P}_{\mathrm{i}}$ formed.

The inhibition by $P_{i}$ is probably the reason why in the cascade reaction (Figure 4) starting from DHA using the soluble AP, a very low product concentration is found. Once an inhibitory concentration of Pi is formed, formation of DHAP will slow down and as a result the aldol reaction catalysed by the aldolase will slow down significantly. Thus the strong inhibition by phosphate prevents application of the soluble enzyme in one-pot cascade reactions. However, the alkaline phosphatase which was immobilized on polymeric porous beads carrying an aldehyde as reactive functionality (Sepabeads EC-HA) was much less sensitive to inhibition by $\mathrm{P}_{\mathrm{i}}$. As a result the DHA cascade reaction using immobilized AP was nearly as efficient as using the immobilized PhoN-Sf. The only difference is that AP only slowly hydrolyses the phosphorylated carbohydrate to the final product. Unfortunately, during turnover the immobilized AP looses it activity much faster that immobilised PhoN-Sf. This may be due to loss of $\mathrm{Zn}^{2+}$ and $\mathrm{Mg}^{2+}$ from the metal binding sites which are not present in PhoN-Sf.

In contrast to our findings with PhoN-Sf (Babich et al., 2011) very little product was formed in the cascade reaction starting from $0.5 \mathrm{M}$ glycerol using immobilized AP. It was however possible to improve this by increasing the concentration of glycerol to $3 \mathrm{M}$. This shows that the glycerol cascade reaction using AP requires further fine-tuning of the conditions to optimize the product formation.

We conclude that alkaline phosphatase from bovine intestine may be a substitute for acid phosphatase in enzyme cascade reactions only under particular conditions, such as using the immobilized enzyme. Although immobilization decreased the inhibitory effect of $\mathrm{P}_{\mathrm{i}}$ on AP, the use of this enzyme in the cascade reaction carried out at higher $\mathrm{pH}$ value did not result in larger product formation compared to PhoN-Sf. Thus in general the acid phosphatases have advantages. However, the use of immobilized AP in the phosphorylation of substrates that are unstable under acidic conditions is a viable option. Further the enzyme is present in many organisms and it may well be that AP from other sources are less prone to inhibition by phosphate. Another option would be to use triphosphate, $\mathrm{PPP}_{\mathrm{i}}$, instead of $\mathrm{PP}_{\mathrm{i}}$ as phosphate donor since this yields in principle more phosphorylated product and upon hydrolysis less free phosphate. Finally we recently developed (Babich et al., 2012b) a new flow process with immobilized acid phosphatase and immobilized aldolase, to synthesize complex chiral carbohydrate analogues from achiral inexpensive building blocks in a three-step cascade reaction. Using immobilized alkaline phosphatase instead of acid phosphatase in such a flow system would allow the physical separation of immobilized AP from the Pi formed, preventing its inhibition by phosphate.

\section{References}

Asano, Y., Mihara, Y., \& Yamada, H. (1999a). A novel selective nucleoside phosphorylating enzyme from morganella morganii. J. Biosci. Bioeng., 87, 732-738. http://dx.doi.org/10.1016/S1389-1723(99)80145-5

Asano, Y., Mihara, Y., \& Yamada, H. (1999b). A new enzymatic method of selective phosphorylation of nucleosides. J. Mol. Catal B-Enzym., 6, 271-277. http://dx.doi.org/10.1016/S1381-1177(98)00081-2

Auriol, D., Nalin, R., Lefevre, F., Ginolhac, A., De Guembecker, D., \& Zago, C. (2008). Method for preparing C-6 phosphorylated D-aldohexoses and C-6 phosphorylated D-aldohexose derivatives. Retrieved from http://patentscope.wipo.int/search/en/detail.jsf\%3Bjsessionid=3FFBADF483A61ADCF2E1EAF7E65BE61 F.wapp1?docId=WO2008142155\&recNum $=267 \&$ office $=$ \&queryString $=\&$ prevFilter $=\% 2526 \mathrm{fq} \% 253 \mathrm{DDP} \%$ 253A2008\&sortOption $=$ Relevance\&maxRec $=581250$

Babich, L, Hartog, A. F., van Hemert, L. J. C., Rutjes, F. P. J. T., \& Wever, R. (2012b). Synthesis of carbohydrates in a continuous flow reactor by immobilized phosphatase and aldolase. ChemSusChem., 5, 2348-2353. http://dx.doi.org/10.1002/cssc.201200468

Babich, L., Hartog, A. F., van der Horst, M. A., \& Wever, R. (2012a). Continuous-flow reactor-based enzymatic synthesis of phosphorylated compounds on a large scale. Chem-Eur. J., 18, 6604-6609. http://dx.doi.org/10.1002/chem.201200101

Babich, L., van Hemert, L. J. C., Bury, A., Hartog, A. F., Falcicchio, P., van der Oost, J., ... Rutjes, F. P. J. T. (2011). Synthesis of non-natural carbohydrates from glycerol and aldehydes in a one-pot four-enzyme 
cascade reaction. Green Chem., 13, 2895-2900. http://dx.doi.org/10.1039/c1gc15429j

Billich, A., Stockhove, U., \& Witze, H. (1983). Synthesis, conformation and enzymatic properties of 1-( $\beta$-D-allofunuiosyl) uracil and some derivatives. Nucleic Acids Res., 11, 7611-7624. http://dx.doi.org/10.1093/nar/11.21.7611

Breslow, R., \& Katz, I. (1968). Relative reactivities of $p$-nitrophenyl phosphate and phosphorothioate toward alkaline phosphatase and in aqueous hydrolysis. J. Am. Chem. Soc., 90, 7376-7377. http://dx.doi.org/10.1021/ja01028a054

Butterworth, P. J. (1968). The pyrophosphatase activity of pig kidney alkaline phosphatase and its inhibition by magnesium ions and excess of pyrophosphate. Biochem. J., 110, 671-5.

Crans, D. C., \& Whitesides, G. M. (1985a). Glycerol kinase: Substrate specificity. J. Am. Chem. Soc., 107, 7008-7018. http://dx.doi.org/10.1021/ja00310a044

Crans, D. C., \& Whitesides, G. M. (1985b). Glycerol kinase: synthesis of dihydroxyacetone phosphate, sn-glycerol-3-phosphate, and chiral analogs. J. Am. Chem, Soc., 107, 7019-7027. http://dx.doi.org/10.1021/ja00310a045

Eaton, R. H., \& Moss, D. W. (1967). Inhibition of the orthophosphatase and pyrophosphatase activities of human alkaline-phosphatase preparations. Biochem. J., 102, 917-21.

Edwards, B., Sparks, A., Voyta, J., Strong, R., Murphy, O., \& Bronstein, I. (1990). Naphthyl dioxetane phosphates: Synthesis of novel substrates for enzymic chemiluminescent assays. J. Org. Chem., 55, 6225-6229. http://dx.doi.org/10.1021/jo00312a036

Faber, K. (2004). Biotransformations in Organic Chemistry $(5$ th ed.). Berlin: Springer. http://dx.doi.org/10.1007/978-3-642-18537-3

Fernley, H. N. (1971). In P. D. Boyer (Ed.), The Enzymes (pp. 417-447). New York: Academic Press.

Fernley, H. N., \& Walker, P. G. (1967). Studies on alkaline phosphatase. inhibition by phosphate derivatives and the substrate specificity. Biochem. J., 104, 1011-8.

Gross, A., Abril, O., Lewis, J. M., Geresh, S., \& Whitesides, G. M. (1983). Practical synthesis of 5-phospho-D-ribosyl alpha-1-pyrophosphate (PRPP): Enzymatic routes from ribose 5-phosphate or ribose. $J$. Am. Chem. Soc., 105, 7428-7435. http://dx.doi.org/10.1021/ja00363a037

Heimbach, T., Oh, D. M., Li, L. Y., Forsberg, M., Savolainen, J., Leppänen, J., ... Fleisher, D. (2003). Absorption rate limit considerations for oral phosphate prodrugs. Pharm. Res., 20(6), 848-856. http://dx.doi.org/10.1023/A:1023827017224

Koyama, T., Inoue, H., Ohnuma, S., \& Ogura, K. (1990). Prenyltransferase reaction involving enantiomeric discrimination. enzymatic synthesis of (S)-10, 11-epoxyfarnesol from racemic 6, 7-epoxygeranyl diphosphate and isopentenyl diphosphate. Tetrahedron Lett., 31, 4189-4190. http://dx.doi.org/10.1016/S0040-4039(00)97578-6

Le Du, M. H., Stigbrand, T., Taussig, M. J., Menez, A., \& Stura, E. A. (2001). Crystal structure of alkaline phosphatase from human placenta at 1.8 A resolution - implication for a substrate specificity. J. Biol. Chem., 276, 9158-9165. http://dx.doi.org/10.1074/jbc.M009250200

Li, C., Enomoto, H., Hayashi, Y., Zhao, H., \& Aoki, T. (2010). Recent advances in phosphorylation of food proteins: A review. LWT - Food Sci. Technol., 43, 1295-1300. http://dx.doi: 10.1016/j.lwt.2010.03.016

Low, M. G., \& Saltiel, A. R. (1988). Structural and functional roles of glycosyl-phosphatidylinositol in membranes. Science, 239, 268-275. http://dx.doi.org/10.1126/science.3276003

Mihara, Y., Utagawa, T., Yamada, H., \& Asano, Y. (2000). Phosphorylation of nucleosides by the mutated acid phosphatase from Morganella morganii. Appl. Environ. Microbiol., 66, 2811-2816. http://dx.doi.org/10.1128/AEM.66.7.2811-2816.2000

Mihara, Y., Utagawa, T., Yamada, H., \& Asano, Y. (2001). Acid phosphatase/phosphotransferases from enteric bacteria. J. Biosc. Bioeng., 92, 50-54. http://dx.doi.org/10.1016/S1389-1723(01)80198-5

Millan, J. L. (2006). Alkaline phosphatases : Structure, substrate specificity and functional relatedness to other members of a large superfamily of enzymes. Purinerg. Signal., 2(2), 335-41. http://dx.doi.org/10.1007/s11302-005-5435-6

Min, J. K., Yoo, H. S., Lee, E. Y., Lee, W. J., \& Lee, Y. M. (2002). Simultaneous quantitative analysis of 
sphingoid base 1-phosphates in biological samples by o-phthalaldehyde precolumn derivatization after dephosphorylation with alkaline phosphatase. Anal. Biochem., 303, 167-175. http://dx.doi.org/10.1006/abio.2002.5579

Morton, R. K. (1955). The substrate specificity and inhibition of alkaline phosphatases of cow's milk and calf intestinal mucosa. Biochem. J., 61, 232-40.

Nayudu, P. R., \& Miles, P. L. (1969). Inhibition of pyrophosphatase activity of mouse duodenal alkaline phosphatase by magnesium ions. Biochem. J., 115, 29-35.

Portmann, P. (1957). [Intestinal alkaline phosphatase]. [Zur Kenntnis der alkalischen Darmphosphatase]. H.-S. Z. Physiol. Chem., 309, 87-128. http://dx.doi.org/10.1515/bchm2.1958.309.1.87

Pradines, A., Klaebe, A., Perie, J., Paul, F., \& Monsan, P. (1988). Enzymatic synthesis of phosphoric monoesters with alkaline phosphatase in reverse hydrolysis conditions. Tetrahedron, 44, 6373-6386. http://dx.doi.org/10.1016/S0040-4020(01)89825-2

Pradines, A., Klaebe, A., Perie, J., Paul, F., \& Monsan, P. (1991). Large-scale enzymatic-synthesis of glycerol-1-phosphate. Enzyme Microb. Techn., 13, 19-23. http://dx.doi.org/10.1016/0141-0229(91)90183-B

Reid, T. W., \& Wilson, I. B. (1971). The Enzymes. New York: Academic Press.

Scudder, P. R., Dwek, R. A., Rademacher, T. W., \& Jacob, G. S. (1991). Phosphorylated glycosidase inhibitor prodrugs. Retrieved from http://www.patentstorm.us/patents/5043273.html

Stadtman, T. C. (1961). Alkaline phosphatases. New York: Academic Press.

Stec, B., Holtz, K. M., \& Kantrowitz, E. R. (2000). A revised mechanism for the alkaline phosphatase reaction involving three metal ions. J. Mol. Biol., 299, 1303-1311. http://dx.doi.org/10.1006/jmbi.2000.3799

Sträter, N., Lipscomb, W. N., Klabunde, T., \& Krebs, B. (1996). Two-Metal ion catalysis in enzymatic acyl- and phosphoryl transfer reactions. Ang. Chem. Int. Edit., 35, 2024-2055. http://dx.doi.org/10.1002/anie.199620241

Tanaka, N., Hasan, Z., Hartog, A. F., van Herk, T., \& Wever, R. (2003). Phosphorylation and dephosphorylation of polyhydroxy compounds by class A bacterial acid phosphatases. Org. Biomol. Chem., 1, 2833-2839. http://dx.doi.org/10.1039/b304012g

Taylor, R. F. (1985). A comparison of various commercially-available liquid-chromatographic supports for immobilization of enzymes and immunoglobulins. Anal. Chim. Acta, 172, 241-248. http://dx.doi.org/10.1016/S0003-2670(00)82611-2

Van Herk, T., Hartog, A. F., Babich, L., Schoemaker, H. E., \& Wever, R. (2009). Improvement of an acid phosphatase/DHAP-dependent aldolase cascade reaction by using directed evolution. ChemBioChem, 10, 2230-2235. http://dx.doi.org/10.1002/cbic.200900102

Van Herk, T., Hartog, A. F., Schoemaker, H. E., \& Wever, R. (2006). Simple enzymatic in situ generation of dihydroxyacetone phosphate and its use in a cascade reaction for the production of carbohydrates: Increased efficiency by phosphate cycling. J. Org. Chem., 71, 6244-6247. http://dx.doi.org/10.1021/jo060644a

Van Herk, T., Hartog, A. F., van der Burg, A. M., \& Wever, R. (2005). Regioselective phosphorylation of carbohydrates and various alcohols by bacterial acid phosphatases; probing the substrate specificity of the enzyme from Shigella flexneri. Adv. Synth. Catal, 347, 1155-1162. http://dx.doi.org/10.1002/adsc.200505072

Westheimer, F. H. (1987). Why nature chose phosphates. Science, 235, 1173-1178. http://dx.doi.org/10.1126/science.2434996

Zubriene, A., Budriene, S., Lubiene, J., \& Dienys, G. (2002). Immobilized alkaline phosphatase for molecular cloning. Biocatal. Biotransform., 20, 423-427. http://dx.doi.org/10.1080/1024242021000040873

\section{Copyrights}

Copyright for this article is retained by the author(s), with first publication rights granted to the journal.

This is an open-access article distributed under the terms and conditions of the Creative Commons Attribution license (http://creativecommons.org/licenses/by/3.0/). 